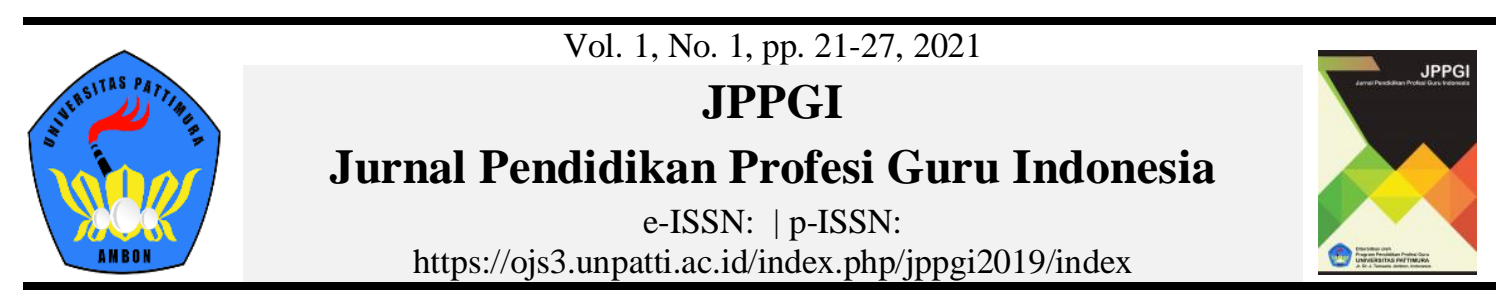

\title{
Organizational Development and Change Along with the Reinventing in Education
}

\begin{abstract}
Zainuddin Notanubun*, Ribka Lemy Ririhena
Department of Primary Education, Faculty of Teacher Training and Education, Universitas PattimuraAmbon, Indonesia

*Corresponding e-mail: z_notanubun1956@gmail.com

Received: 10 August $2020 \quad$ Accepted: 29 November $2020 \quad$ Online Published: 08 February 2021

Abstract: The purpose of organizational development, especially educational organizations, is the formation of an educational organization in the provincial and district/city governments, so that education units at all types and levels are open and generate trust for educators and their communities. Organizational open and generate trust for educators and their communities. Organizational development interventions tend to emphasize the application of collaborative or interpersonal and group strategies in inter-organizational actions in a coordinative or vertical manner, in accordance with the spirit of reinvention. In restructuring educational organizations or reinventing education to increase the activities and programs of the Provincial, Regency and City Education Offices in carrying out routine activities, they must be changed, no longer using a bureaucratic approach with a participatory approach. The paradigm of education officials must be changed, so that in accordance with the spirit of the implementation of school-based management in schools. By giving a large role to schools in the spirit of change, the school has a high creativity to compete in improving the quality and quality of education in the school.
\end{abstract}

Keywords: Development, Change, Organization, Reinventing

To cite this article:

Notanubun, Z., \& Ririhena, R. L. (2021). Organizational development and change along with the reinventing in education. JPPGI: Jurnal Pendidikan Profesi Guru Indonesia, 1(1), 21-27.

\section{INTRODUCTION}

Organizational development considered as a serious matter if people think that the most important change strategy in society is politics, law, and technology (Tsai, 2011). Organizational change is another way to reinvent an organization, therefore there is a guarantee that the organization can work affective, efficient, humane, and competitive (Smollan, 2017).

Organizational development has a threat to changes planned from time to time which is sought to improve the quality of education (Turi, Sorooshian, \& Javed, 2019). In developing organizations there are certain changes as a system. National education development in the reform era, which is often mentioned by education experts or bureaucrats in the field of education, is as a hope to improve the quality of education in this country. Until now, there are various innovation strategies that have not yet materialized (Tometich, Fracasso, Zen, \& Engelman, 2019). 
The development of education is very fast, in accordance with the development of technology and information in the midst of society (Macgilchrist, Allert, \& Bruch, 2019). Thus, the educational process not only prepares students to be able to live in today's society, but prepares them to live in a future society, whose characteristics are increasingly difficult to predict. This is due to the fact that in this global era, the development of society is not linear anymore, but full of discontinuity. Therefore, past successes do not necessarily have validity to handle and resolve current and future educational problems (Kunst, Kuhn, \& van de Werfhorst, 2019).

There are three things that constitute challenges for Indonesia's education in the future. First, global currents that have taken place since the early 1990s and are still being felt today (Rizvi, 2004). Second, the education system is still looking for stability (Munro, 2016). Third, the cultural values of Indonesian people who have not been able to put in place a renewal process, such as shortcuts, undisciplined, egocentric, and patrimodialism (Riany, Meredith, \& Cuskelly, 2016).

To create and nurture and prepare community members to be strong, institutions and education systems must support it to function optimally. The system on the one hand provides ample means and infrastructure, and on the other hand builds and nurtures educators to be strong, competent enough to maintain their self-esteem and authority and economic well-being in order to function optimally.

\section{METHOD}

This research uses a library method, with a Qualitative approach. Qualitative research is required to be able to organize all the theories that are read (Sutton \& Austin, 2015). The study of theory in research is more functional to show how far the researcher has the theory and understand the problem under study. In addition, qualitative research is actually required to conduct grounded research, which is finding theories based on data obtained in the field or social situations.

\section{RESULT AND DISCUSSION}

\section{Organizational Development}

Development in the organization consist of objectives to be achieved, work rules, norms that must be obeyed, methods and procedures in carrying out work, unity of direction and command, coordination, control and cooperation. Social relations among the people in it, as well as appreciation for everyone who has carried out their work to develop the organization (Bakker, DeFillippi, Schwab, \& Sydow, 2016).

Organizational development is a planned effort, started by experts as a process to help an organization, develop diagnostic skills, mastery abilities, relationship strategies in the form of temporary or half-fixed systems and cultural equality (Ruben, 2005).

Organizational culture is what is felt and how this perception creates a pattern of trust, values, and expectations or culture as a pattern of basic acceptance when found, or developed by certain groups (Knein, Greven, Bendig, \& Brettel, 2019). This is an effort to learn to overcome the problems of external adaptation and internal integration that have worked smoothly enough to become a more sustainable organizational development.

Organizational development is a planned process, managed systematically to change the culture, systems, and behavior of the organization, in order to increase the effectiveness of the organization in solving problems and achieving goals (Weiner, 
Notanubun, Z., \& Ririhena, R. L., Organizational development and change... | 23

2009). Including formal organizational restructuring that is often raised, facilitated, and driven by normative and behavioral changes.

Organizational development is a planned effort, started by experts as a process to help an organization develop diagnostic skills, mastery capabilities, relationship strategies in the form of temporary or semi-permanent systems and cultural and cultural equality organization (Griffith, Baur, \& Buckley, 2019). The culture in question starts from the formal statement of top management, where ethical behavior is the norm in an individual's actions in the organization.

The purpose of developing organizations, especially educational organizations, is the formation of an educational organization in the provincial and district / city governments so that education units at all types and levels are open, creating trust for educators and their communities. Organizational development interventions tend to emphasize the application of collaborative or interpersonal and group strategies in interorganizational actions in a coordinative or vertical manner.

The aim of organizational development focus at the changing of attitudes or values, modifying behavior, and inducing changes in structure and policy. Organizational development practitioners generally implement collaborative or interpersonal or work group change strategies, and focus on human variables to help organize the wheels of the organization. The use of the same change strategy every time according to Hersey and Blanchaed (1982) can lead to effective change in certain situations, but not in other situations. This means that there is no best change strategy because it depends on the results of the diagnosis of the situation and determining the approach that has the highest possible success.

Organization is a tool to achieve the goals of various parties outside the organization, and as a tool to achieve organizational goals. For this reason, the organization must be arranged rationally, in the sense that it must be formed and operate based on formal provisions and efficiency calculations, or it can be said that the organization is actually a collection of people that is integrated in a forum for cooperation to ensure the achievement of the goals set (Notanubun, Ririhena, \& Batlolona, 2019).

\section{Organizational Change}

The organization as a container and tool to achieve goals in which there are norms and values that are held fast. However, these norms and values must always adjust to changes that might affect the performance and culture of the organization. The planned target of organizational change is to keep the organization alive and continue to meet the needs of the community (Speziale, 2015).

Organizations that are not conspicuous, and their survival is threatened because management fails to respond to environmental changes. This choice is difficult because if it remains in a position of success it will provide a sense of security to the organization, whereas if making changes and renewing yourself will carry risks.

However, it is realized that in any organization that wants to progress and develop must adjust to the development of its time, including educational organizations. Based on Law No. 22 of 1999 concerning regional autonomy, the organization and management of national education became more flexible. As stated in the decision of the Minister of National Education Number 010 / O / 2000, regarding the organization and work procedures of the Ministry of National Education as follows: (1) Ministry 
level, (2) Provincial Level, (3) District / City Level, (4) District Level , and (5) School / Educational Provider.

Based on Law No. 5/1974 concerning the Principles of regional government in Indonesia, applies three principles, namely decentralization, deconcentration, and coadministration. This law is a preparation towards the issuance of Law No. 22 of 1999 concerning regional autonomy. Decentralization is defined as the transfer of governmental affairs to the regions so that the authority and responsibilities that were previously carried out by the central government, are now handed over to the regional authorities, including making policies, making decisions, planning, financing, and supervising them (Kigume \& Maluka, 2019).

Autonomy in education must also change. One example is schools that have been running school organizations only principals and teachers with their parents, should involve people who have concern for education, as well as community leaders and employers to join the school committee.

Changes in school organizations by involving community participation to think about the development of education in schools, especially in school management can encourage the community to give input to the government, both internally and externally. This has a positive impact on the government to improve the quality of education in stages starting from schools to the education council and from the education council to the regional government.

Internal input, is the school committee organization also evaluates learning planning, process, and evaluation. Including being involved in determining the curriculum applied at the school. While externally, the school committee organization was involved in making the school's budget and income plans, and the school's continuous development plan for internal quality improvement through student learning outcomes. In addition, making plans for improving quality externally through school accreditation.

The School Committee can carry out its role and function as a support in the implementation of the learning process that is in line with the conditions and environmental problems of each school. The school committee can carry out its function as a school partner in the provision of educational resources in the context of implementing education management that can create facilities for teachers and students to learn so that learning becomes more effective. Synergy between the school committee and the school creates a shared responsibility between the school and the community as partners in developing education.

The community will be able to channel various ideas and participation in advancing education in their area. The school must be able to convince parents, the local government, the business community, and the community at large that the school can be trusted. Thus, schools at the technical level need to develop the ability to analyze school fees that correlate significantly with the quality of education that they get.

Managing organizations experiencing change, while changes also occur in the curriculum. Although this is a government policy in this case the Ministry of Education, but its implementation is actually implemented by schools. Related to the shift in management models and also the competency-based curriculum (KBK) to the 2013 curriculum (K-13), the impact of these changes makes schools have to make cultural changes. The principle is that there is no total management and curriculum change, but adjustments are made that are familiar with the school environment. 
Notanubun, Z., \& Ririhena, R. L., Organizational development and change... 25

\section{Reinventing Educational Organizations}

The general characteristics of bureaucratic reform and organization, especially educational organizations in "reinventing" can be divided at four levels as follows; (1) the national macro strategic policy setting related to national standardization of education is carried out by the Ministry of National Education, (2) the regional macro level setting is to take policies to facilitate the development, coordination and supervision of strategic programs coordinatively in their function as assistance carried out by the province, (3) level of implementation of broad autonomy in accordance with the aspirations of the regions in providing services for school and non-school needs carried out by districts and cities, (4) the setting of education with the principle of professionalism, namely developing creativity and innovation in organizing school management and providing learning services for students, by schools according to their authority and authority to determine quality and quality standards. Growth in positions of structural officials and teachers and functional officials (Sagala, 2008).

Prior to the implementation of the regional autonomy policy, the activities of educational organizations in the regencies and cities were to serve schools such as staffing affairs, school accreditation, school construction permits, etc. to be forwarded to the province, because the bureaucracy was hierarchical from district and city to the province. After the implementation of the regional autonomy policy, all personnel, licensing, budget, facilities and infrastructure matters, the authority to manage them is delegated (decentralized) from the province to the district / city. Except for school accreditation which is still handled at the provincial level. Educational organizations after the implementation of regional autonomy are generally described as follows.

1. In an effort to guarantee the provision of education services, the central Government, namely the Ministry of National Education (Depdiknas) as an assistant to the President with his authority, is responsible for the implementation of National education with the authority to take national strategic program policies. the program includes setting educational quality standards, competency standards for students and learning citizens, quality measurement standards such as curriculum, evaluation of learning outcomes, academic calendar, teacher and education personnel competency requirements, nationally and implementation guidelines. In relation to regional autonomy, the province is an extension of the central government called "deconstration", vertically part of the central and provincial government authority is decentralized, namely the flexibility of decisions transferred to district / city governments more quickly to solve problems.

2. As confirmed by Article 3 paragraph 10 PP No.25 of 2000. point C of the province has the authority to organize Extraordinary Schools (SLB) relating to personnel affairs, facilities, curriculum, student affairs, and supervision. The authority of decentralization and the authority of deconcentration to carry out their duties and arrange development and assistance programs. The province on the one hand functions as an "autonomous" region, on the other hand the authority as an administrative area. Relationship of the Governor and Regents / Mayors in the context of cross-Regency / City deconcentration and autonomy (1) determining the policy of accepting students and students from minority, backward and unable communities; (2) providing basic textbooks / education modules for kindergarten, basic education, secondary education, and non-school education; (3) organizing special schools and training centers and / or upgrading teachers. This is done in the form of functional technical coordination carried out by the provincial education 
office.

3. The district / city government is responsible for operational services in the administration of education in the region, carrying out the authority of district / city regional autonomy in the framework of implementing regional autonomy to provide guidance and service for the administration of school and non-school programs. This namely services for educational needs, personnel affairs, budget, material as products contribute to the quality of education in kindergarten, junior high school, high school, and outside school or education units (Sagala Syaiful, 2008).

Based on the description above, it can be raised that educational organizations in the regions are designed to improve the governance and management of the education sector to become increasingly necessary. Adjusting more autonomous organizations will of course require not only an increase in the capacity of its human resources and encouragement to demand better services, but also more strength to improve the duties of the education service, among others; (1) developing standards that demand school empowerment, based on norms, regulations or guidelines, (2) convincing people to know what standards they are entitled to and expect, and (3) ensuring that the existence of education in the system autonomy, the provincial and district / city governments provide education at the level of priority they deserve.

\section{CONCLUSION}

All levels and types of educational organizations, ranging from the central government to schools actually influence each other. It consists of a variety of strategies, and organizational competition in pursuit of high strategic competitiveness and excellence. The rearrangement of the design of educational organizations that are truly capable of empowering schools according to their autonomous rights is very much needed.

Rearranging the design of educational organizations that provide services to the public in accordance with public demands for an effective organization. Rearranging the design of educational organizations, is intended to find a balance or combination between elements that are centralized or decentralized.

In reorganizing educational organizations or reinventing education, it is necessary to change routine activities to increase the activities and programs of the Provincial, District and City Education Offices. Don't use the bureaucratic approach anymore, but you must use a participatory approach. The paradigm of education officials must be changed, from an intructive approach to participatory. This is in line with the spirit of implementing school-based management. Thus, the school with the committee can plan, implement programs that suit the needs of the school.

\section{REFERENCES}

Bakker, R. M., DeFillippi, R. J., Schwab, A., \& Sydow, J. (2016). Temporary Organizing: Promises, Processes, $\quad$ Problems. $\quad$ Organization $\quad$ Studies, $37(12), \quad 1703-1719$. https://doi.org/10.1177/0170840616655982

Griffith, J. A., Baur, J. E., \& Buckley, M. R. (2019). Creating comprehensive leadership pipelines: Applying the real options approach to organizational leadership development. Human Resource Management Review, 29(3), 305-315. https://doi.org/10.1016/j.hrmr.2018.07.001

Hersey, P., \& Blanchard, K. A. (1982). Management of Organizational Bahavior: Utilizing Human Resources. New Delhi: PrenticeHall of India

Kigume, R., \& Maluka, S. (2019). Decentralisation and health services delivery in 4 districts in Tanzania: How and why does the use of decision space vary across districts? International Journal of Health 
Policy and Management, 8(2), 90-100. https://doi.org/10.15171/ijhpm.2018.97

Knein, E., Greven, A., Bendig, D., \& Brettel, M. (2019). Culture and cross-functional coopetition: The interplay of organizational and national culture. Journal of International Management, (January), 100731. https://doi.org/10.1016/j.intman.2019.100731

Kunst, S., Kuhn, T., \& van de Werfhorst, H. G. (2019). Does education decrease Euroscepticism? A regression discontinuity design using compulsory schooling reforms in four European countries. European Union Politics. https://doi.org/10.1177/1465116519877972

Macgilchrist, F., Allert, H., \& Bruch, A. (2019). Students and society in the 2020s. Three future 'histories' of education and technology. Learning, Media and Technology, O(0), 1-14. https://doi.org/10.1080/17439884.2019.1656235

Munro, J. (2016). The violence of inflated possibilities : education, transformation, andd iminishment in wamena, PAPUA. 95(95), 25-46.

Notanubun, Z., Ririhena, R. L., \& Batlolona, J. R. (2019). The effect of organization restructuring on organization performance viewed from employee performance and leadership effectiveness at maluku provincial education office. Journal of Education and Learning (EduLearn), 13(1), 118. https://doi.org/10.11591/edulearn.v13i1.11222

Riany, Y. E., Meredith, P., \& Cuskelly, M. (2016). Understanding the Influence of Traditional Cultural Values on Indonesian Parenting Understanding the Influence of Traditional Cultural Values on Indonesian Parenting. 4929(March). https://doi.org/10.1080/01494929.2016.1157561

Rizvi, F. (2004). Debating globalization and education after September 11. Comparative Education, 40(2), 157-171. https://doi.org/10.1080/0305006042000231338

Ruben, B. D. (2005). The Center for Organizational Development and Leadership at Rutgers University: A Case Study. Advances in Developing Human Resources, 7(3), 368-395. https://doi.org/10.1177/1523422305277177

Sagala, S. (2008). Budaya dan Reinventing Organisasi Pendidikan. Pemberdayaan Organisasi Pendidikan ke Arah yang Lebih Profesional dan Dinamis di Provinsi/Kota dan Satuan Pendidikan. Bandung: Penerbit Alfabeta

Smollan, R. K. (2017). Supporting staff through stressful organizational change. Human Resource Development International, 20(4), 1-23. https://doi.org/10.1080/13678868.2017.1288028

Speziale, G. (2015). Strategic management of a healthcare organization: Engagement, behavioural indicators, and clinical performance. European Heart Journal, Supplement, 17, A3-A7. https://doi.org/10.1093/eurheartj/suv003

Sutton, J., \& Austin, Z. (2015). Qualitative research: Data collection, analysis, and management. Canadian Journal of Hospital Pharmacy, 68(3), 226-231. https://doi.org/10.4212/cjhp.v68i3.1456

Tometich, P., Fracasso, E., Zen, A., \& Engelman, R. (2019). The decision to innovate and the movement of dynamic capabilities. Gestao e Producao, 26(2), 1-13. https://doi.org/10.1590/0104-530X-362719

Tsai, Y. (2011). Relationship between organizational culture, leadership behavior and job satisfaction. BMC Health Services Research, 11(1), 98. https://doi.org/10.1186/1472-6963-11-98

Turi, J. A., Sorooshian, S., \& Javed, Y. (2019). Impact of the cognitive learning factors on sustainable organizational development. Heliyon, 5(9), e02398. https://doi.org/10.1016/j.heliyon.2019.e02398

Weiner, B. J. (2009). A theory of organizational readiness for change. Implementation Science, 4(1), 1-9. https://doi.org/10.1186/1748-5908-4-67 